Pesq. Vet. Bras. 30(7):581-585, julho 2010

\title{
Effect of medroxy-progesterone acetate on follicular growth and endometrial cycloxygenase-2 (COX-2) expression during the bovine estrous cycle ${ }^{1}$
}

\begin{abstract}
Valério M. Portela ${ }^{2 *}$, Alexandre M. Farias², José C. Ferrugem Moraes ${ }^{3}$, Paulo Bayard D. Gonçalves ${ }^{2}$, Angela P. Medeiros Veiga ${ }^{4}$ and João F. Oliveira ${ }^{2}$

ABSTRACT.- Portela V.M., Farias A.M., Moraes J.C.F., Gonçalves P.B.D., Veiga A P.M. \& Oliveira J.F. 2010. Effect of medroxy-progesterone acetate on follicular growth and endometrial cycloxygenase-2 (COX-2) expression during the bovine estrous cycle. Pesquisa Veterinária Brasileira 30(7):581-585. Laboratório de Biotecnologia e Reproducão Animal, Universidade Federal de Santa Maria, Av. Roraima s/n, Santa Maria, RS 97105900, Brazil. E-mail: valerio.portela@gmail.com

The objective of this study was to evaluate the effect of medroxy-progesterone acetate (MAP) with or without estradiol benzoate (EB) on follicular growth during the estrous cycle in cattle. In the first experiment, Hereford cows were synchronized with a synthetic analogue of PGF 2 alpha and were treated with two different doses of MAP (250 or $500 \mathrm{mg}$ ) with or without EB for 7 days starting on day 8 of the estrous cycle. Follicular growth was inhibited $(P<0.05)$ in all cows except controls and those receiving 250mg MAP without EB. Seventyfive percent of the animals (15/20) showed estrus on days 21 and 22 of the cycle rather than at MAP withdrawal, demonstrating that these treatments did not induce estrus. To determine whether the EB treatment altered endometrial sensitivity to oxytocin and thus the luteolytic cascade, multiparous pre-synchronized cows received $5 \mathrm{mg}$ of EB followed 6 hours later with $50 \mathrm{IU}$ of oxytocin (OT; $n=9$ ). Eight hours after EB injection, endometrial fragments were collected from the cows on days 4,13 and 17 of the estrous cycle and COX-2 gene expression was measured by PCR. EB increased COX-2 mRNA levels only on day 17 of the estrous cycle $(P<0.05)$. In conclusion, MAP alone or associated with EB is able to suppress bovine follicular growth. However, EB in the presence of MAP is not efficient to induce luteolysis in cows when injected on day 8 of the estrous cycle.
\end{abstract}

INDEX TERMS: Follicular growth, estradiol benzoate, medroxy-progesterone acetate, beef cattle, luteolysis.

RESUMO.- [Efeito do acetato de medroxi-progesterona sobre o crescimento filicular e expressão endometrial de ciclooxigenase-2 (COX-2) durante o ciclo estral de bovinos.] Este estudo teve como objetivo avaliar o efeito

\footnotetext{
${ }^{1}$ Received on June 26, 2009.

Accepted for publication on January 6, 2010.

2 Laboratório de Biotecnologia e Reproducão Animal, Universidade Federal de Santa Maria (UFSM), Av. Roraima s/n, Santa Maria, RS 97105-900, Brazil. *Corresponding author: valerio.portela@ gmail.com

${ }^{3}$ Embrapa Pecuária Sul, BR 153 Km 603, Bagé, RS 96401-970, Brazil.

${ }^{4}$ Departamento de Patologia Clínica Veterinária, Universidade Federal do Rio Grande do Sul (UFRGS), Av. Bento Gonçalves 9090, Porto Alegre, RS 91540-000, Brazil.
}

do acetato de medroxi-progesterona (MAP) com ou sem benzoato de estradiol (BE) sobre o crescimento folicular durante o ciclo estral bovino. No primeiro experimento, vacas da raça Hereford foram sincronizadas com um análogo sintético de PGF2á e tratadas com duas doses diferentes de MAP ( 250 ou $500 \mathrm{mg}$ ), com ou sem EB, durante 7 dias, iniciando-se no oitavo dia do ciclo estral. Observou-se uma inibição do crescimento folicular $(P<0,05)$ em todas as vacas, exceto no grupo controle e no grupo que recebeu $250 \mathrm{mg}$ de MAP sem $\mathrm{BE}$. Os $75 \%$ dos animais não exibiu estro no momento da remoção do MAP, mas sim nos dias 21 e 22 do ciclo, demonstrando que os tratamentos não induziram cio. Para se determinar se o tratamento com $\mathrm{BE}$ alterou a sensibilidade endometrial à ocitocina e, assim, a cascata luteolítica, vacas multíparas 
pré-sincronizadas receberam $5 \mathrm{mg}$ de $\mathrm{BE}$, seguidos, após 6 horas, de $50 \mathrm{UI}$ de ocitocina (OT; n=9). Oito horas após a administração de BE, colheram-se fragmentos endometriais das vacas, nos dias 4, 13 e 17 do ciclo estral, mensurando-se a expressão gênica de COX-2 através de PCR. O BE aumentou os níveis de RNAm de COX-2 apenas no dia 17 do ciclo estral $(P<0,05)$. Em conclusão, 0 MAP isolado ou associado a BE é capaz de suprimir o crescimento folicular bovino. Entretanto, o BE, na presença de MAP é ineficaz na indução da luteólise bovina, quando injetado no oitavo dia do ciclo estral.

TERMOS DE INDEXAÇÃO: Crescimento folicular, benzoato de estradiol, acetato de medroxi-progesterona, bovinos de corte, luteólise.

\section{INTRODUCTION}

Although the use of progesterone to inhibit ovulation and synchronize estrus has been widely employed in cattle (Martìnez et al. 2007, Small et al. 2009), the use of synthetic progestins in cattle is less well known. Medroxyprogesterone acetate (MAP) is cheaper than natural progesterone and is a potentially good option for extensive farming practices in Brazil. MAP has been used to induce estrus in post-partum beef cattle (Medeiros Bastos et al. 2004, Terra et al. 2008), and its use in synchronization of cyclic cattle within an Ovsynch protocol has been reported (Cavestany et al. 2003, Terra et al. 2008). Depending on stage of cycle, the dominant follicle subject to exposure to MAP may be the follicle that ovulates at MAP withdrawal (Burke et al. 1996), therefore the impact of MAP synchronization protocols on follicle dynamics requires elucidation.

High concentrations of progesterone have been shown to limit follicular growth (Adams et al. 1992, Burke et al. 1996) and induce atresia of persistent follicles (Savio et al. 1993, Stock \& Fortune 1993, Anderson \& Day 1994). Additionally, exogenous estradiol induces atresia of the dominant follicle (Bo et al. 1995, Kinder et al. 1996) and induces luteolysis (Thatcher et al. 1986), leading to the emergence of a new follicle wave 3 to 4 days after the initiation of treatment (Kinder et al. 1996). Although the feedback mechanisms of estradiol and progesterone on LH secretion are different (Price \& Webb 1988), when administered in combination, estradiol greatly enhances the ability of progesterone to suppress the LH surge in ovariectomized ewes and cows (Stumpf et al. 1993, Cupp et al. 1995). The effect of exogenous estradiol on MAP synchronization protocols is not known.

The aim of this experiment was to determine the influence of two different concentrations of MAP, with or without exogenous estradiol, on follicular growth and induction of estrus under typical extensive farming conditions in Brazil. As the expression of estrus is dependent on the ability of treatments to induce luteolysis, we also measured the effect of exogenous estradiol on uterine sensitivity to oxytocin.

\section{MATERIALS AND METHODS}

\section{Experiment 1}

Twenty Hereford cows at a body condition score of 4 ( $1=$ =ean; $5=$ overweight) were housed at the Embrapa Sul experimental farm in Bagé, Rio Grande do Sul. The animals were presynchronized by an injection of 500 $\mu$ g of cloprostenol (Sincrocio, Ourofino, Brazil). Twenty-four hours later, the animals were observed for detection of estrus.

After the detection of estrus, the animals were randomly allocated to one of 5 groups as follows: control group $(n=3)$; group MAP250BE $(n=4)$ received an intra-vaginal device (IVD) with 250mg MAP (Purifarma, SP, Brazil) and an intramuscular (IM) injection of $5 \mathrm{mg}$ of estradiol benzoate (EB) (Purifarma, SP, Brazil) diluted in vegetable oil; group MAP250 $(n=5)$ received an IVD containing 250mg MAP; group MAP500BE $(n=4)$ received an IVD containing 500mg MAP and an IM injection of $5 \mathrm{mg}$ of EB diluted in vegetable oil; and group MAP500 $(n=4)$ received an IVD containing 500mg MAP. The treatments were given on day 8 of the estrous cycle. The IVDs were removed on the day 14 of estrous cycle, and estrus detection started thereafter.

All groups were evaluated by ultrasound through a Pie Medical model 480 (Pie Medical, The Netherlands) equipped with a transrectal linear $5 \mathrm{MHz}$ real time transducer, and connected to a VHS recorder set. During each evaluation, a complete scanning of the ovaries was performed, and the diameters of the largest and second largest follicles were measured. The evaluations took place on the first day of the treatment and once every 2 days for 14 days.

\section{Experiment 2}

Animals and sample collection. Eighteen Red Angus and Nelore-cross cows, between three and four years old, were raised extensively in a private farm in Sao Gabriel, Rio Grande do Sul, Brazil. Every animal was pre-synchronized with 500 $\mu \mathrm{g}$ cloprostenol. The animals were separated in two groups. The treated animals $(n=9)$ received $5 \mathrm{mg}$ EB and followed six hours later with $50 \mathrm{IU}$ oxytocin (OT) (Placentina, Usinas Chimicas Brasileiras S.A., Brazil). The control group $(n=9)$ received $50 \mathrm{IU}$ OT only. The treatments were applied at three different moments of estrous cycle, day 4,13 or 17 ; thus there were three animals per group/time (2 Angus and 1 Nelore). The OT challenge was used because estradiol upregulates OT receptor mediated expression of COX-2 (Burke et al. 1996). Two hours after OT injection, fragments of endometrium were collected under sedation and caudal epidural anesthesia. An incision was performed on the dorsal region of the vagina, vertically and over the first portion of the cervix. The tissues were stored in RNA Later $₫$ (Qiagen) and frozen in liquid nitrogen. All animal procedures were approved by the Bioethics Committee of the College of Veterinary Medicine, Federal University of Santa Maria.

Nucleic acid extraction \& semi-quantitative RT-PCR. Gene expression was assayed by RT-PCR. Total RNA (1 mg) was first treated with $1 \mathrm{U}$ DNase (Promega, Madison, WI) at $37^{\circ} \mathrm{C}$ for 30 min to digest any contaminating DNA, followed by adding $1 \mathrm{ml}$ EDTA stop buffer at $65^{\circ} \mathrm{C}$ for $10 \mathrm{~min}$. The RNA was reverse transcribed in the presence of $1 \mathrm{mM}$ oligo(dT) primer and $4 \mathrm{U}$ Omniscript RTase (Qiagen, USA), 0.25mM dideoxynucleotide triphosphate (dNTP) mix, and 19.33 U RNase Inhibitor (Amersham Biosciences, USA) in a volume of $20 \mathrm{ml}$ at $37^{\circ} \mathrm{C}$ for $1 \mathrm{~h}$. The reaction was terminated by incubation at $93^{\circ} \mathrm{C}$ for $5 \mathrm{~min}$. 
Bovine-specific primers for COX-2 (Pfaffl et al. 2003) and histone $\mathrm{H} 2 \mathrm{a}$ (Hayashi et al. 2003) were used. PCR of fixed amounts of RNA indicated that $\mathrm{H} 2 \mathrm{a}$ amplicon abundance was stable across treatments, whereas amounts of another housekeeping gene, glyceraldehyde-3-phosphate dehydrogenase, were found to vary. An aliquot $(1 \mathrm{ml})$ of the cDNA template was amplified by PCR using $0.25 \mathrm{ml}$ (2.5 U) Taq Polymerase (Amersham Pharmacia Biotech Inc., USA) in a 20-ml PCR buffer (Amersham Pharmacia Biotech Inc.) containing $0.1 \mathrm{mM}$ dNTP mix, and $0.2 \mathrm{mM}$ specific primers. After an initial denaturation step for 3 min at $94^{\circ} \mathrm{C}$, target cDNA was amplified with a denaturation step at $94^{\circ} \mathrm{C}$ for $60 \mathrm{sec}$, annealing for $45 \mathrm{sec}$ at $60^{\circ} \mathrm{C}(\mathrm{COX}-2)$ or at $58^{\circ} \mathrm{C}$ for $30 \mathrm{sec}(\mathrm{H} 2 \mathrm{a})$, and elongation at $72^{\circ} \mathrm{C}$ for $1 \mathrm{~min}$. All reactions were terminated with a final elongation at $72^{\circ} \mathrm{C}$ for $5 \mathrm{~min}$. Reactions was performed for 30 cycles for COX-2 and for $\mathrm{H} 2 \mathrm{a}, 29$ cycles.

The PCR products were separated on $2 \%$ agarose gels containing $0.001 \%$ ethidium bromide, and visualized under UV light. Quantification of band intensity was performed with Image $\mathrm{J}(\mathrm{NIH}, \mathrm{USA})$. The use of animals in these experiments was in accordance with the Guide to the Care and Use of Experimental Animals (Canadian Council on Animal Care, 315-350 Albert Street, Ottawa, Ontario, K1R 1B1) and was approved by the animal care committee of the authors' institution.
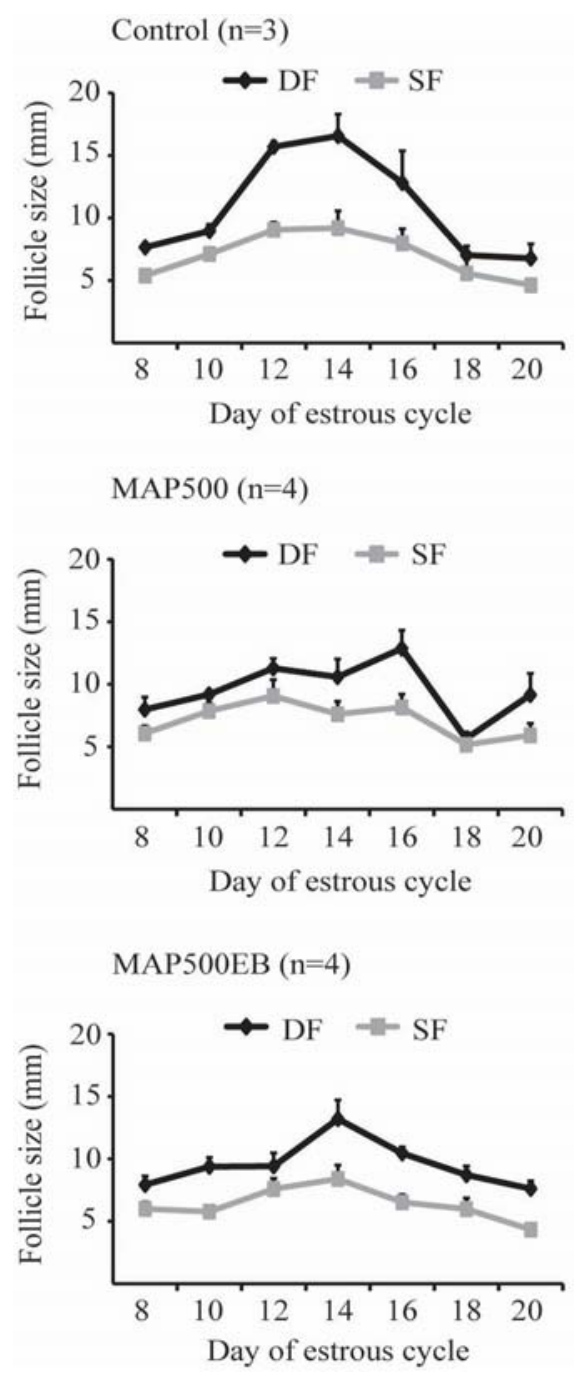

\section{Statistical analysis}

The effect of treatments on diameter of the largest follicle was tested by ANOVA. Dominance was determined by measuring the diameters of the two largest follicles by ultrasound. ANOVA for repeated measures was used to compare results in the same group, where the class was the day and the factor of repetition was the cow.

Data that did not follow a normal distribution pattern (ShapiroWilk's test) were transformed to logarithms. Homogeneity of variance was tested with O'Brien and Brown-Forsythe's tests. All analytical procedures were performed with JMP software (SAS Institute, USA) with treatment group as main effect and cow replicate as a random variable in F-test. For gene expression data, housekeeping gene abundance was included as a covariate in the main effects model. Differences between means were tested with the Tukey-Kramer's HSD test. Data are presented as means \pm SEM.

\section{RESULTS}

Experiment 1. Wave dynamics of the dominant and subordinate follicles in each treatment group are shown in Figure 1. The growth of the dominant follicle was suppressed in animals receiving $500 \mathrm{mg}$
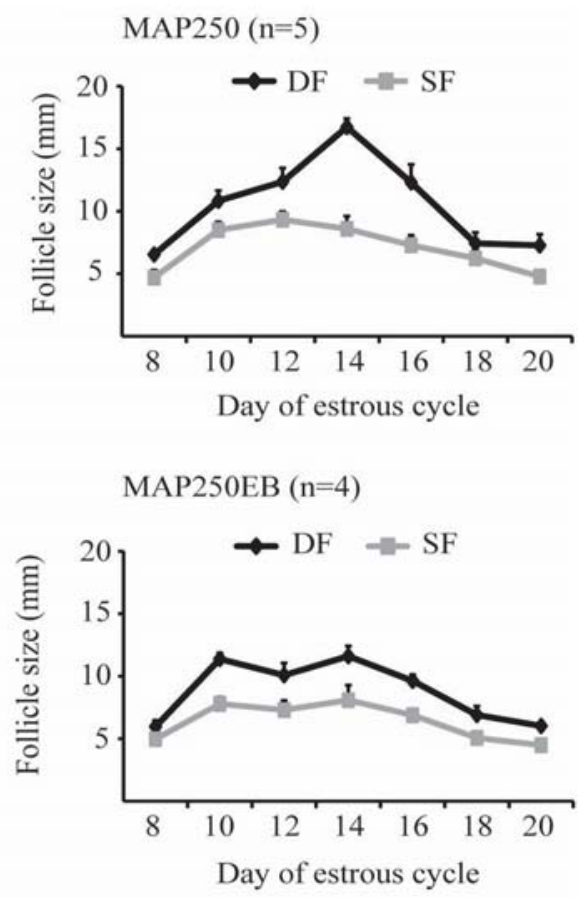

Fig.1. Diameters of the dominant (DF) and largest subordinate (SF) follicles in cattle receiving intravaginal devices containing 250 or $500 \mathrm{mg}$ MAP, with or without EB. Devices were inserted on day 8 and removed on day 14. Follicle diameters were recorded by transrectal ultrasonography. The number of animals in each group is given in each panel. Data are presented as means \pm SEM. 


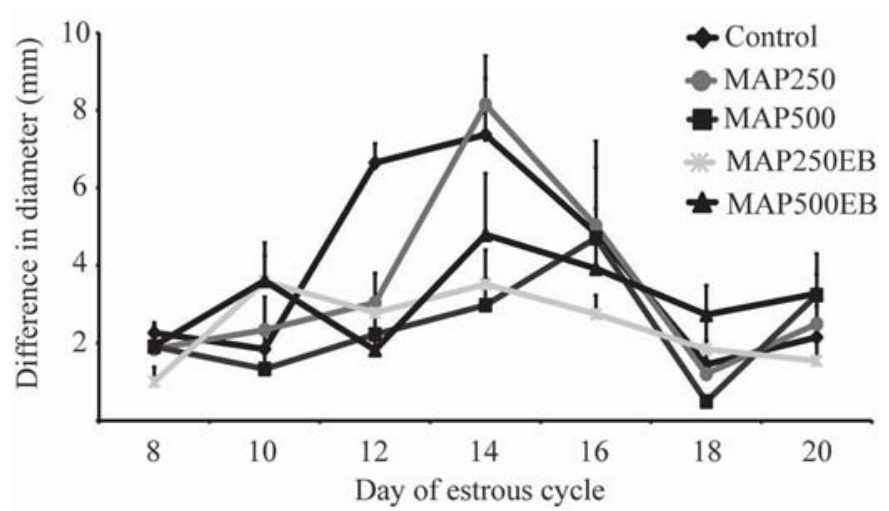

Fig.2. Effect of treatments on the difference in diameter between the dominant and subordinate follicle during the treatment estrous cycle. Animals received intravaginal devices containing 250 or $500 \mathrm{mg}$ MAP, with or wit hout EB. Devices were inserted on day 8 and removed on day 14. Data are presented as means.

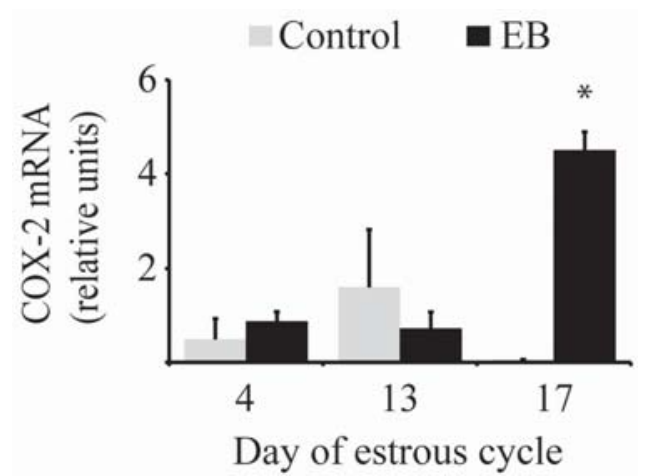

Fig.3. Effect of estradiol benzoate (EB) treatment on oxytocininduced COX-2 mRNA abundance in the endometrium on days 4, 13 and 17 of the cycle. Animals were injected with EB or saline $6 \mathrm{~h}$ before injection of oxytocin. Endometrial samples were collected $2 \mathrm{~h}$ later. COX-2 mRNA was measured by RT-PCR. Data are presented as means \pm SEM and asterisk indicates a significant effect of $E B(P<0.05)$.

MAP with or without EB, and in animals receiving 250mg MAP with EB $(P<0.05)$. The maximum diameter of the dominant follicle in the 250mg MAP group without EB was not different from the controls. A difference in diameter between the two largest follicles was detected only in Control and MAP250 groups $(P<0.05)$ (Fig.2), indicating the presence of follicular waves in those two groups. Estrus was not detected after withdrawal of IVDs as expected, but occurred on days 21 and 22 of the estrous cycle in $75 \%$ of the animals; the remainder had not shown estrus by day 22 .

Experiment 2. EB significantly $(P<0.05)$ increased endometrial COX-2 mRNA abundance on day 17 of the cycle, but had no effect on days 4 and 13 of the cycle (Fig.3) irrespective of the treatment with exogenous estradiol.

\section{DISCUSSION}

The use of synthetic progestins in IVD is not widespread in cattle. The objective of this study was to determine the effects of MAP on follicle dynamics, and whether exogenous estradiol was capable of inducing luteolysis and a new follicle wave. This information has implications for implanting simple and cost effective estrus synchronization protocols suitable for extensive farming practices in Brazil.

Altering progesterone concentrations during the cycle has impact on gonadotropin secretion. High levels inhibit LH pulse secretion whereas lower sub-luteal levels result in raised LH secretion (Stock \& Fortune 1993). Extended periods under sub-luteal concentrations of progesterone, such as CIDR or MAP synchronization protocols, prolong the period of follicular dominance, maintain high levels of estradiol, and reduce oocyte viability and fertility (Stock \& Fortune 1993, Mihm et al. 1994). In Experiment 1, we demonstrated that MAP at a dose of $250 \mathrm{mg}$ alone is incapable of blocking follicular growth, whereas at the higher dose of MAP, the dominant follicle failed to reach its normal size. These data agree with earlier studies, in which $300 \mathrm{mg}$ MAP failed to alter the growth of the dominant follicle (Cavestany et al. 2003), or where rising concentrations of the synthetic progestin norgestomet inhibited growth of the dominant follicle (Sanchez et al. 1995).

It is known that estradiol enhances the inhibitory influence of progestagens on LH release (Price \& Webb 1988). In agreement with this, the addition of EB to the 250mg MAP dose inhibited follicle growth compared to MAP alone. Although LH pulse secretion was not measured, it is likely that EB enhanced the inhibitory effect of progesterone on LH pulse frequency. Despite the inhibition of follicle growth during MAP+EB treatment, data suggest that follicle growth following IVD removal is not affected by pretreatment with MAP (Borges et al. 2008).

In the present experiment, estrus was not synchronized but occurred at the normal time, on day 21 and 22 of the cycle. This was because the animals were pre-synchronized with $P G$ and all treatments started on day 8 of the cycle. All animals thus had a functional corpus luteum during and after IVD placement. This designed allowed the study of follicle dynamics under controlled conditions, and allowed us to determine whether EB would cause luteolysis in this model. As the follicle data and lack of estrus synchronization shows, EB did not induce luteolysis when given with MAP on day 8 of the cycle.

Estradiol is believed to induce luteolysis by increasing endometrial OT receptor expression, and thus OT induction of COX-2 and PG synthesis (Thatcher et al. 1986, Kombe et al. 2003). To determine whether the inability of EB treatment to induce estrus in this study was related to responsiveness to OT, COX-2 mRNA levels were assessed following OT challenge. EB did not increase COX-2 expression until day 17 of the cycle, consistent with the lack of luteolysis and synchronization of estrus observed in Experiment 1. This is later than the mid-cycle response reported earlier (Thatcher et al. 1986), and may be influenced by dose of EB or OT used in the present study.

In conclusion higher doses of MAP alone or lower doses of MAP in conjunction with EB are able to suppress growth of the dominant follicle in cattle. Although the injection of 
EB at start of MAP treatment was potent in suppressing follicle growth, it did not induce luteolysis at midcycle.

Acknowledgements.- To Dr. Christopher Price, University of Montreal, for suggestions and English reviews. To PRONEX/CNPq, FAPERGS and CAPES for the financial support and scholarship. To Embrapa Pecuária Sul and Agropecuária Vila Nova for providing the animals and physical space available for these experiments.

\section{REFERENCES}

Adams G.P., Matteri R.L. \& Ginther O.J. 1992. Effect of progesterone on ovarian follicles, emergence of follicular waves and circulating follicle-stimulating hormone in heifers. J. Reprod. Fertil. 96:627-640.

Anderson L.H. \& Day M.L. 1994. Acute progesterone administration regresses persistent dominant follicles and improves fertility of cattle in which estrus was synchronized with melengestrol acetate. J. Anim. Sci. 72:2955-2961.

Bo G.A., Adams, G.P., Caccia M., Martinez M., Pierson R.A. \& Mapletoft R.J. 1995. Ovarian follicular wave emergence after treatment with progestogen and estradiol in cattle. Anim. Reprod. Sci. 39:193-204.

Borges L.F.K., Ferreira R., Siqueira L.C., Bohrer R.C., Borstmann J.W., Oliveira J.O.F.C.D. \& Gonçalves P.B.D. 2009. Artificial insemination system without estrous observation in suckled beef cows. Ciência Rural 39:496-501.

Burke C.R., Macmillan K.L. \& Boland M.P. 1996. Oestradiol potentiates a prolonged progesterone-induced suppression of $\mathrm{LH}$ release in ovariectomised cows. Anim. Reprod. Sci. 45:13-28.

Cavestany D., Meikle A., Kindahl H., Van Lier E., Moreira F., Thatcher W.W. \& Forsberg M. 2003. Use of medroxyprogesterone acetate (MAP) in lactating Holstein cows within an Ovsynch protocol: Follicular growth and hormonal patterns. Theriogenology 59:1787-1798.

Cupp A.S., Stumpf T.T., Kojima F.N., Werth L.A., Wolfe M.W., Roberson M.S., Kittok R.J. \& Kinder J.E. 1995. Secretion of gonadotrophins change during the luteal phase of the bovine oestrous cycle in the absence of corresponding changes in progesterone or 17 [beta]oestradiol. Anim. Reprod. Sci. 37:109-119.

Hayashi K., Acosta T.J., Berisha B., Kobayashi S.I., Ohtani M., Schams D. \& Miyamoto A. 2003. Changes in prostaglandin secretion by the regressing bovine corpus luteum. Prostaglandins other Lipid Mediat. 70:339-349.

Kinder J.E., Kojima F.N., Bergfeld E.G., Wehrman M.E. \& Fike K.E. 1996. Progestin and estrogen regulation of pulsatile LH release and development of persistent ovarian follicles in cattle. J. Anim. Sci. 74:1424-1440.
Kombe A., Sirois J. \& Goff A.K. 2003. Prolonged progesterone treatment of endometrial epithelial cells modifies the effect of estradiol on their sensitivity to oxytocin. Steroids 68:651-658.

Martìnez M.F., Kastelic J.P., Colazo M.G. \& Mapletoft R.J. 2007. Effects of estradiol on gonadotrophin release, estrus and ovulation in CIDRtreated beef cattle. Domest. Anim. Endocrinol. 33:77-90.

Medeiros Bastos G., Brenner R.H., Willke F.W., Neves J.P., De Oliveira J.F.C., Bragança J.F.M., Machado S.A., Porciuncula P.M. \& Gonçalves P.B.D. 2004. Hormonal induction of ovulation and artificial insemination in suckled beef cows under nutritional stress. Theriogenology 62:847-853.

Mihm M., Baguisi A., Boland M.P. \& Roche J.F. 1994. Association between the duration of dominance of the ovulatory follicle and pregnancy rate in beef heifers. J. Reprod. Fertil. 102:123-130.

Pfaffl M.W., Wittmann S.L., Meyer H.H.D. \& Bruckmaier R.M. 2003. Gene Expression of Immunologically Important Factors in Blood Cells, Milk Cells, and Mammary Tissue of Cows. J. Dairy Sci. 86:538545.

Price C.A. \& Webb R. 1988. Steroid control of gonadotrophin secretion and ovarian function in heifers. Endocrinology 122:2222-2231.

Sanchez T., Wehrman M., Kojima F., Cupp A., Bergfeld E., Peters K., Mariscal V., Kittok R. \& Kinder J. 1995. Dosage of the synthetic progestin, norgestomet, influences luteinizing hormone pulse frequency and endogenous secretion of 17 beta-estradiol in heifers. Biol. Reprod. 52:464-469.

Savio J.D., Thatcher W.W., Badinga L., De La Sota R.L. \& Wolfenson D. 1993. Regulation of dominant follicle turnover during the oestrous cycle in cows. J. Reprod. Fertil. 97:197-203.

Small J.A., Colazo M.G., Kastelic J.P. \& Mapletoft R.J. 2009. Effects of progesterone presynchronization and eCG on pregnancy rates to GnRH-based, timed-Al in beef cattle. Theriogenology 71:698-706.

Stock A.E. \& Fortune J.E. 1993. Ovarian follicular dominance in cattle: relationship between prolonged growth of the ovulatory follicle and endocrine parameters. Endocrinology 132:1108-1114.

Stumpf T., Roberson M., Wolfe M., Hamernik D., Kittok R. \& Kinder J. 1993. Progesterone, 17 beta-estradiol, and opioid neuropeptides modulate pattern of luteinizing hormone in circulation of the cow. Biol. Reprod. 49:1096-1101.

Terra G.H., Gonçalves P.B.D., Oliveira J.F.C., Weimer T.A. \& Neves J.P. 2008. Indução da ovulação em vacas de corte com diferentes ofertas forrageiras durante o período pós-parto. Ciênc. Anim. Bras. 9:219-225.

Thatcher W.W., Terqui M., Thimonier J. \& Mauleon P. 1986. Effect of estradiol-17[beta] on peripheral plasma concentration of 15-keto,14dihydro PGF2[alpha] and luteolysis in cyclic cattle. Prostaglandins 31:745-756. 